\title{
Public knowledge, beliefs and practices in Greece about cancer etiology and prevention
}

\author{
K. Charalabopoulos, ${ }^{1}$ G. Makris, ${ }^{2}$ A. Charalabopoulos, ${ }^{1}$ C. Golias ${ }^{7}$ and K. Athanasiou ${ }^{2}$
}

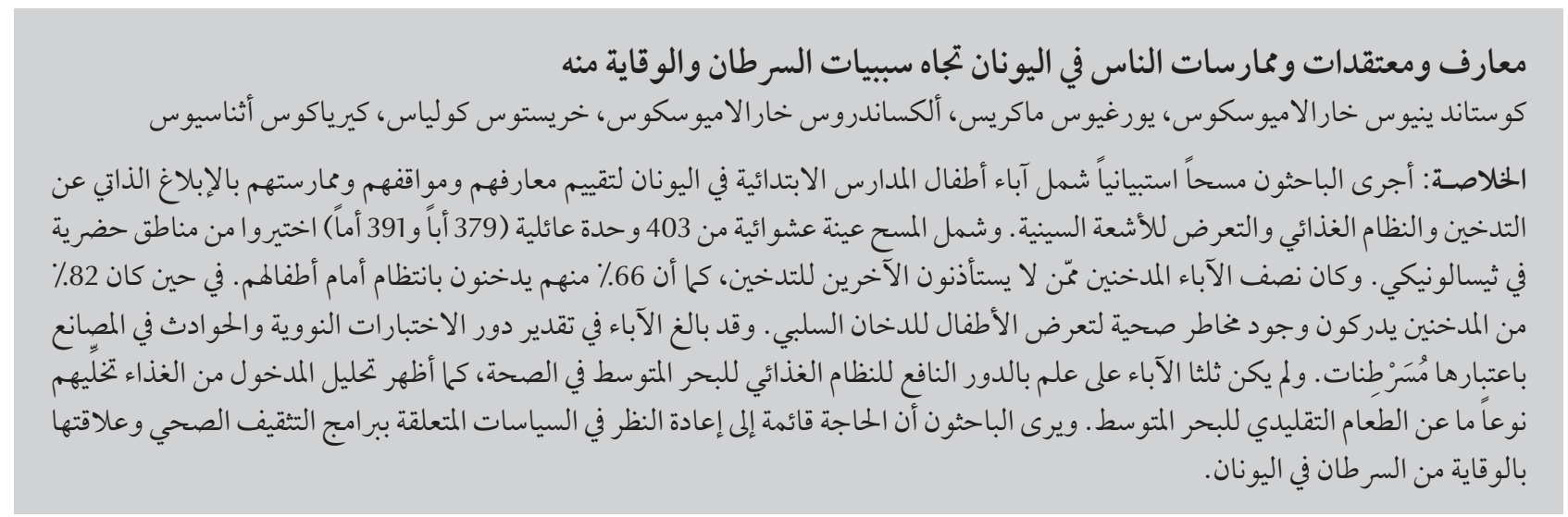

ABSTRACT This questionnaire survey of the parents of elementary schoolchildren in Greece assessed their selfreported knowledge, attitudes and practices towards smoking, diet and exposure to X-radiation. A random sample of 403 household units (379 fathers and 391 mothers) was selected from urban areas of Thessaloniki. Half of the parents who smoked (50.1\%) did not ask for permission to smoke from other people and $66.0 \%$ regularly smoked in front of their children. On the other hand, $82.6 \%$ of smokers recognized the existence of a health risk to children from passive smoking. Parents overestimated the role of nuclear tests and accidents as factors in carcinogenesis. Two-thirds of parents did not know the beneficial role of the Mediterranean diet to health, and dietary intake analysis showed some departure from the traditional Mediterranean diet. A reconsideration of the policy regarding health education programmes concerning cancer prevention in Greece is needed.

Connaissances, croyances et pratiques de la population grecque en matière d'étiologie du cancer et de sa prévention

RÉSUMÉ La présente enquête a évalué par questionnaire les connaissances, attitudes et pratiques autodéclarées des parents d'écoliers du primaire en matière de consommation de tabac, d'alimentation et d'exposition aux rayons X en Grèce. Un échantillon de 403 ménages (379 pères et 391 mères) a été sélectionné aléatoirement dans les zones urbaines de Thessalonique. La moitié des parents fumeurs $(50,1 \%)$ ne demandait pas la permission aux autres pour fumer et 66,0 \% fumaient régulièrement devant leurs enfants. Toutefois, 82,6 \% des fumeurs reconnaissaient l'existence d'un risque pour la santé des enfants à cause du tabagisme passif. Les parents surestimaient le rôle des essais et accidents nucléaires en tant que facteurs dans la cancérogenèse. Deux tiers des parents ignoraient le rôle bénéfique du régime méditerranéen pour la santé et l'analyse de leurs apports alimentaires a révélé un certain éloignement de ce régime traditionnel. La politique des programmes d'éducation sanitaire en matière de prévention du cancer doit être reconsidérée en Grèce.

'Department of Physiology, Clinical Unit, Ioannina University Medical School, Ioannina, Greece (Correspondence to K. Charalabopoulos: kcharala@cc.uoi.gr).

${ }^{2}$ School of Education, Aristotelian University of Thessaloniki, Thessaloniki, Greece.

Received: 17/06/09; accepted: 15/10/09 


\section{Introduction}

Intense efforts to tackle cancer with improvements in treatment have not had the desired results, and preventionoriented strategies are increasingly being promoted $[1,2]$. The role that environmental and lifestyle factors, including diet and smoking, can play in cancer causation and prevention is attracting increasing interest in the research community [3-5]. The growing body of evidence in this area has led to the development of various nutritional guidelines for cancer prevention $[6,7]$. Factors such as intake of selenium, glutathione, essential fatty acids, dietary fibre, antioxidants (resveratrol and polyphenols) and vitamins $\mathrm{E}$ and $\mathrm{C}$ have been associated with reduced cancer risk, promoting specific dietary recommendations for the prevention and management of cancer [8]. Foremost among these is the diet of the Mediterranean region, which is low in saturated fat and is believed to offer many health benefits, including improved glucose metabolism with decreased risk of type 2 diabetes and of obesity and protection from cardiovascular disease $[5,9,10]$. Reduced risk of breast, ovarian, colorectal and upper aerodigestive tract malignancies have also been associated with the Mediterranean diet [8].

It is especially important for young people to have information about healthy diets and the risks of long-term exposure to carcinogens. Children of pre-school and school age are therefore important targets of interventions for the prevention of cancer or the establishment of habits that may help to reduce the risk of cancer later in life [11]. However, to maximize the effectiveness of such initiatives, it is first necessary to understand the knowledge and beliefs of the target population. Children's knowledge, attitudes and practices are strongly influenced by their parents $[12,13]$. This study of the parents of elementary schoolchildren in Greece, a Mediterranean country, aimed to assess their self-reported knowledge, attitudes, beliefs and practices towards smoking, diet and exposure to X-radiation. It forms part of a wider project to study aspects of cancer prevention in different strata of Greek society [14].

\section{Methods}

A questionnaire survey was made of the parents of elementary schoolchildren in Thessaloniki, the second largest city in Greece, which has a population of around 1.5 million.

\section{Sample}

During a 2-month school period (March 2008 toApril 2008) a random sample of 403 households units were selected consisting of 379 fathers and 391 mothers of children attending elementary public schools in urban areas of Thessaloniki. The selection of schools and children was done in a random and systematic procedure using the school lists for Thessaloniki. Although the city of Thessaloniki is characterized by a certain degree of homogeneity in the socioeconomic characteristics of the families of its public schools pupils, we excluded 4 of the schools that were judged to be extremes because of their high proportion of Roma students who have certain special characteristics (e.g. intermittent school attendance and pupils being removed by parents to perform pedlar work).

\section{Data collection and analysis}

A structured, self-reported questionnaire was completed by the parents. Trained interviewers delivered the questionnaire to the parents, gave them instructions and explained any difficult items. However, they did not intervene in the responses to the questions, in order not to influence the parents' opinion. None of the parents refused to participate in the study.

The 79-item questionnaire covered 4 main categories: sociodemographic data (sex, age, occupational status and area of residence); perceptions about smoking habit (both fathers and mothers); perceptions about the cases of cancer and the importance of a range of potential environmental carcinogens (e.g. atmospheric pollution, radiation etc.); consumption of a range of dietary items; and whether they had received any type of education about cancer prevention. The questionnaire was initially tested on a $10 \%$ sample of the total sample in order to establish the validity and reliability of the method.

For statistical analysis the chisquared test and nonparametric tests were used, with a $P$-value $<0.05$ as the level of significance.

\section{Results}

The mean age of the 379 fathers was 41 (SD 12) years and of the 391 mothers was 37 (SD 14) years.

\section{Smoking practices and beliefs}

Analysis of parents' smoking habits shows that 205/379 (54.1\%) of fathers and $168 / 391(43.0 \%)$ of mothers were regular smokers (smoking daily) or occasional smokers (1-5 cigarettes weekly). Smoking consumption analysis showed that $68 / 92(73.9 \%)$ of father-smokers and 88/135 (65.2\%) of mother-smokers smoked 10-40 cigarettes daily.

The percentage of father- and mother-smokers (regular and occasional smokers) who reported that they do not ask for permission to smoke from other people were $61.5 \%$ and $36.3 \%$ respectively ( $50.1 \%$ overall) (Table 1$)$. In addition, $75.1 \%$ of father-smokers and $54.8 \%$ of mother-smokers reported that they regularly smoked in front of their children ( $66.0 \%$ overall).

On the other hand, $82.6 \%$ of the total sample believed that smoking in the presence of children was harmful to children's' health, while the corresponding percentage for non-smokers was 


\begin{tabular}{|c|c|c|c|}
\hline \multicolumn{4}{|c|}{$\begin{array}{l}\text { Table } 1 \text { Parents' self-reported smoking practices and beliefs (regular and } \\
\text { occasional smokers only) }\end{array}$} \\
\hline Variable & $\begin{array}{l}\text { Fathers } \\
(n=205)\end{array}$ & $\begin{array}{l}\text { Mothers } \\
(n=168)\end{array}$ & $\begin{array}{c}\text { Total } \\
(n=373)\end{array}$ \\
\hline & $\%$ & $\%$ & $\%$ \\
\hline \multicolumn{4}{|c|}{ Smoke in front of children } \\
\hline Yes & 75.1 & 54.8 & 66.0 \\
\hline No & 11.2 & 12.5 & 11.8 \\
\hline Sometimes & 13.7 & 32.7 & 22.2 \\
\hline \multicolumn{4}{|c|}{$\begin{array}{l}\text { Ask permission to smoke in } \\
\text { front of other people }\end{array}$} \\
\hline Yes & 31.2 & 59.5 & 44.0 \\
\hline No & 61.5 & 36.3 & 50.1 \\
\hline Sometimes & 7.3 & 4.2 & 5.9 \\
\hline \multicolumn{4}{|c|}{ Plan to quit smoking } \\
\hline Yes & 62.4 & 68.5 & 65.1 \\
\hline No & 17.1 & 15.5 & 16.0 \\
\hline Don't know & 20.5 & 16.1 & 18.7 \\
\hline \multicolumn{4}{|c|}{$\begin{array}{l}\text { Think they are able to quit } \\
\text { smoking }\end{array}$} \\
\hline Yes & 44.6 & 56.0 & 49.6 \\
\hline No & 32.7 & 23.8 & 28.7 \\
\hline Don't know & 22.8 & 20.2 & 21.9 \\
\hline \multicolumn{4}{|c|}{ Ever attempted to quit smoking } \\
\hline Yes & 63.9 & 60.7 & 61.9 \\
\hline No & 36.1 & 39.3 & 38.1 \\
\hline
\end{tabular}

$96.0 \%$. Some parents (14.0\%) thought the main risk of smoking was influencing children's behaviour.

The main reason for starting smoking among fathers was feeling that they became more adult (30.2\%), whereas among mothers the main reason was the calming effect of smoking (30.4\%). Two-thirds of respondents (62.4\% of father-smokers and $68.5 \%$ of mother-

\begin{tabular}{|c|c|c|c|}
\hline \multicolumn{4}{|c|}{$\begin{array}{l}\text { Table } 2 \text { Parents' beliefs about the effect of smoking in the presence of children } \\
\text { (total sample) }\end{array}$} \\
\hline Variable & $\begin{array}{l}\text { Fathers } \\
(n=379)\end{array}$ & $\begin{array}{l}\text { Mothers } \\
(n=391)\end{array}$ & $\begin{array}{c}\text { Total } \\
(n=770)\end{array}$ \\
\hline & $\%$ & $\%$ & $\%$ \\
\hline Is harmful to children's health & 85.0 & 80.3 & 82.6 \\
\hline Is not harmful to children's health & 0.5 & 0.5 & 0.5 \\
\hline Influences children's behaviour & 11.6 & 16.4 & 14.0 \\
\hline $\begin{array}{l}\text { Does not influence children's } \\
\text { behaviour }\end{array}$ & 2.4 & 2.8 & 2.6 \\
\hline Don't know & 0.5 & 0.0 & 0.3 \\
\hline
\end{tabular}

mainly hereditary, infectious or viral in origin. There was no statistically significant difference $\left(\chi^{2}\right.$-test, $\left.P>0.05\right)$ between the sexes in their views about the causes of cancer (Table 3). When asked about the role of various X-ray radiation sources involved in carcinogenesis; $33.9 \%$ of parents associated the induction of cancer mainly with nuclear tests and $30.0 \%$ with nuclear accidents.

\section{Education about cancer risk and prevention}

When asked about their exposure to sources of information about cancer only $7.5 \%$ of parents were aware of specific campaigns that had been organized by medical societies or institutions. The majority $(82.7 \%)$ indicated that occasional free lectures on health education were their main source of information, while TV programmes, newspapers and magazines informed $32.7 \%$ of them.

\section{Dietary intake}

The household respondents of the families were asked to indicate their weekly consumption of various food items (Table 4). According the dietary recall, $85.0 \%$ of households consumed meat 1-3 times, while 9.4\% consumed it 4-6 times weekly. At the same time household respondents denied (17.9\%) or did not know about (42.7\%) any health risks from excessive meat consumption. The majority of respondents reported that they preferred to eat their meat well-done $(71 \%)$. The majority of the households consumed vegetables 4-7 times weekly (69.0\%) and fruits 4-7 times weekly (82.7\%). However, they rarely consumed wholewheat and rye bread (73.9\% and $94.5 \%$ respectively).

The majority of the parents (fathers and mothers) did not know the beneficial role of the Mediterranean diet to health (65\% of fathers and $62 \%$ of mothers respectively). From the total sample of parents only $7 \%$ could recognize the food items in a list of items of the Mediterranean type diet. 


\begin{tabular}{|c|c|c|c|}
\hline \multirow[t]{2}{*}{ Variable } & $\begin{array}{l}\text { Fathers } \\
(n=379)\end{array}$ & $\begin{array}{c}\text { Mothers } \\
(n=391)\end{array}$ & $\begin{array}{c}\text { Total } \\
(n=770)\end{array}$ \\
\hline & $\%$ & $\%$ & $\%$ \\
\hline \multicolumn{4}{|l|}{ Main cause of cancer } \\
\hline Hereditary & 50.9 & 51.9 & 46.8 \\
\hline Infectious & 44.8 & 42.9 & 48.4 \\
\hline Viral & 4.2 & 5.1 & 4.6 \\
\hline \multicolumn{4}{|l|}{$\begin{array}{l}\text { Main risk to health from } \\
\text { radiation }\end{array}$} \\
\hline Dental X-ray & 1.0 & 1.5 & 1.3 \\
\hline Chest X-ray & 7.8 & 8.8 & 8.3 \\
\hline Cosmic radiation and radon & 11.8 & 13.1 & 12.4 \\
\hline Nuclear accidents & 28.5 & 31.8 & 30.0 \\
\hline Nuclear tests & 38.2 & 29.2 & 33.9 \\
\hline All of the above & 12.8 & 15.6 & 14.1 \\
\hline
\end{tabular}

\section{Discussion}

During recent years heart disease and cancer have become the main public health problems in Greece, a country that during previous decades had some of the best records for these diseases [15]. Among the causes of this epidemiological transition might be changes in lifestyle, increased tobacco consumption, higher per capita income, changes in food consumption patterns and ineffective preventive measures [15].

The choice of parents (fathers and mothers) as the target population in our study was motivated by the role which parents exercise in relation to young children's beliefs and practices. Greece has the highest per capita consumption of cigarettes among European Union countries [16]. The results of our survey of smoking by smoker-parents are quite discouraging. Although as many as $82.6 \%$ of the total sample knew about the health risks to children from passive exposure to cigarette smoke, $75.1 \%$ of fathers and $54.8 \%$ of mothers who were regular or occasional smokers reported that they regularly smoked in front of their children $[17,18]$. In addition, only $43.9 \%$ of the parent-smokers of our sample ask permission to smoke in front of other people. These figures are very close to the findings of a similar study that we conducted with Greek university students [14]. We found a difference between the sexes in their reasons for smoking. The main reason for starting smoking among males was feeling that they were more adult (30.2\%), whereas among females the main reason was the calming effect of smoking (30.4\%).

Discouraging findings were observed in the weekly meat consumption of households, the ways of cooking and their knowledge about the existence of health risks from the excess meat consumption. Most of the households (95.3\%) consumed meat 1-7 times weekly. In addition, the overwhelming majority of them preferred their meat well-done $(71.0 \%)$. This shows that they may be are unaware of the risks that may be related to well-done food items, especially meat, due to the production of hydrocarbons and aromatic amines produced by food pyrolysis $[6,19]$.

Other aspects of the nutritional habits were also disappointing, suggesting that there might be some departure from the traditional Mediterranean diet in Greek households. This may lead to an increased risk for future health problems to parents and their children $[6,20,21]$. Based on recent data of the Hellenic Cancer Society it is estimated that the proportion of colorectal cancer cases that are directly associated with diet in Greece represent $8.5 \%$ of all the total cancer cases in men and $10.6 \%$ in women, with a steadily increasing incidence [22]. Moreover, it is noteworthy that in a recent large, populationbased cohort study Trichopoulos et al. showed that a greater adherence to the Mediterranean diet was associated with a reduction in total mortality due to cancer in Greece [23]. Since Greece is a relatively small country, with a relatively uniform landscape and only 11 million habitants, it was not possible to provide information on different regions of the country. More information will be available from the European Prospective Investigation into Cancer and Nutrition Study [24].

The overwhelming majority of the households almost never or rarely consumed wholewheat and rye bread ( $73.9 \%$ and $94.5 \%$ respectively), foods which are believed to have protective effects on colorectal cancer development $[25,26]$. More encouraging were the findings in relation to the consumption of fruits and vegetables by households; 69.0\% consumed vegetables 4-7 times weekly and $82.7 \%$ fruits $4-7$ times weekly. Nevertheless, these are lower than the recommended dietary intakes in Europe, which are for 2-3 servings of vegetables and 3-4 servings of fruits per day [27]. Thus, while Greek households continue to consume reasonable amounts of vegetables and fruits, there may be a trend towards greater meat and white bread consumption and lower fish and wholewheat bread consumption. The Mediterranean diet is low in saturated fat ( $\leq 7 \%-8 \%$ of energy) with total fat ranging from $<25 \%$ to $>35 \%$ of energy. It is well documented that olive oil and other mono-and unsaturated fats, appear to reduce the risk of some cancer types [14].

Parents overestimated the role of nuclear tests and nuclear accidents as factors involved in carcinogenesis. This may be linked to the nuclear accident 


\begin{tabular}{|c|c|c|c|c|}
\hline \multirow[t]{2}{*}{ Food item } & \multicolumn{4}{|c|}{ Weekly consumption (\% of households) } \\
\hline & $7+$ times & 4-6 times & 1-3 times & Never/rarely \\
\hline \multicolumn{5}{|l|}{ Meat } \\
\hline Sausages & 0.2 & 5.2 & 44.2 & 50.4 \\
\hline Bacon & 0.5 & 0.7 & 8.7 & 90.1 \\
\hline Lamb & 0.0 & 0.0 & 10.9 & 89.9 \\
\hline Pork & 0.2 & 1.5 & 43.9 & 54.3 \\
\hline Veal & 0.2 & 3.0 & 77.7 & 19.1 \\
\hline Beef & 0.0 & 0.0 & 13.4 & 86.6 \\
\hline Chicken & 0.0 & 3.2 & 82.6 & 14.1 \\
\hline Beef liver & 0.3 & 0.9 & 19.3 & 79.6 \\
\hline Meatballs & 0.0 & 3.0 & 63.3 & 33.7 \\
\hline \multicolumn{5}{|l|}{ Fish/seafood } \\
\hline Octopus & 0.0 & 0.7 & 11.4 & 87.8 \\
\hline Sepia & 0.0 & 1.0 & 8.7 & 91.1 \\
\hline Calamari & 0.0 & 1.2 & 21.3 & 77.4 \\
\hline Fish & 1.7 & 8.9 & 78.2 & 11.2 \\
\hline \multicolumn{5}{|l|}{ Breads } \\
\hline Wholewheat bread & 11.9 & 4.0 & 10.2 & 73.9 \\
\hline White bread & 45.9 & 14.4 & 11.7 & 28.0 \\
\hline Rye bread & 1.2 & 0.5 & 3.7 & 94.5 \\
\hline Toasts & 3.7 & 5.5 & 22.1 & 68.7 \\
\hline \multicolumn{5}{|l|}{ Vegetables/fruits } \\
\hline Vegetables & 35.5 & 33.5 & 28.8 & 2.2 \\
\hline Fruits & 56.1 & 26.6 & 11.2 & 6.2 \\
\hline \multicolumn{5}{|l|}{ Nuts/seeds } \\
\hline Nuts & 0.5 & 2.0 & 23.6 & 73.9 \\
\hline Salty nuts & 1.0 & 2.0 & 28.8 & 68.2 \\
\hline \multicolumn{5}{|l|}{ Dairy/fats } \\
\hline Butter & 7.2 & 10.7 & 26.3 & 55.8 \\
\hline Margarine & 6.0 & 9.7 & 22.3 & 62.0 \\
\hline Olive oil & 70.0 & 17.4 & 6.9 & 5.7 \\
\hline Vegetable oil & 13.6 & 12.9 & 36.7 & 36.7 \\
\hline Other & 1.0 & 0.7 & 1.5 & 96.8 \\
\hline
\end{tabular}

in the Ukraine in 1996, in which the probable risks from wind-borne radioactive nuclides (a case that has not been hysteria about the risks from hypothetical excess ambient radioactivity, masking other health messages or risk warnings. The fact that a high percentage of Greek people exaggerate the cancer risks from factors of "minor" importance (e.g. nuclear accidents), equating them with more realistic risks (e.g. smoking and radon exposure) indicate how important it is to adjust health messages according to the population's specific beliefs.

Only $7.5 \%$ of the parents were aware of any specific campaigns to inform the public about cancer risks. The majority indicated that occasional free lectures on health education ( $82.7 \%$ ) were their main source of information, while TV programmes, newspapers and magazines informed $32.7 \%$ of them. The results of our study strongly suggest the need for a re-evaluation of the goals, context and methodology of cancer prevention efforts in Greece. We have already shown in a previous publication that Greek youngsters have little knowledge about specific anticancer campaigns, are the heaviest smokers among European Union nations and have high consumption of meat and saturated fat. On the other hand, they consume good amounts of vegetables and fruits [28]. Because parents have a strong influence on children's knowledge, attitude and practices, Greek parents should be encouraged to continue their consumption of vegetables and fruits, while reducing their consumption of saturated fats, which may have a detrimental effect on their own and their children's health. Meanwhile, anti-smoking campaigns emphasizing the risk of passive smoking need to be intensified.

\section{References}

1. Doll R. Epidemiological evidence of the effects of behaviour and the environment on the risk of human cancer. Recent Results in Cancer Research, 1998, 154:3-21.

2. Bostick RM et al. Knowledge, attitudes, and personal practices regarding prevention and early detection of cancer. Preventive Medicine, 1993, 22:65-85.

3. Anand $\mathrm{P}$ et al. Cancer is a preventable disease that requires major lifestyle changes. Pharmaceutical Research, 2008, 25:2097-2116.
4. Perera FP. Environment and cancer: who are susceptible? Science, 1997, 278:1068-1073.

5. De Lorgeril M, Salen P. The Mediterranean diet: rationale and evidence for its benefit. Current Atherosclerosis Reports, 2008, 10:518-522.

6. Ames BN. Dietary carcinogens and anticarcinogens. Oxygen radicals and degenerative diseases. Science, 1983, 221:12561264. 
7. Moore $\mathrm{H}$ et al. Nutrition and the health care agenda: a primary care perspective. Family Practice, 2000, 17:197-202.

8. Piscopo S. The Mediterranean diet as a nutrition education, health promotion and disease prevention tool. Public Health Nutrition, 2009, 12 9A;1648-1655.

9. Giugliano D, Esposito K. Mediterranean diet and metabolic diseases. Current Opinion in Lipidology, 2008, 19:63-68.

10. Mitrou PN et al. Mediterranean dietary pattern and prediction of all cause mortality in a US population: results from the NIH-AARP Diet and Health Study. Archives of Internal Medicine, 2008, 168:1823-1824.

11. Chin DG et al. Elementary school-age children's developmental understanding of the causes of cancer. Journal of Developmental and Behavioral Pediatrics, 1998, 19:397-403.

12. Harris MB, Harris RJ, Davis SM. Ethnic and gender differences in Southwestern students' sources of information about health. Health Education Research, 1991, 6:31-42.

13. Gibson EL, Wardle J, Watts CJ. Fruit and vegetable consumption, nutritional knowledge and beliefs in mothers and children. Appetite, 1998, 31:205-228.

14. Bosetti C, Pelucchi C, La Vecchia C. Diet and cancer in Mediterranean countries: carbohydrates and fats. Public Health Nutrition, 2009, 12 9A;1595-1600.

15. Kogevinas $M$ et al. Potential years of like lost in Greece, by cause of death. Iatriki, 1992, 62:162-168 [in Greek].

16. 2010 Eurobarometer survey on tobacco. European Public Health Alliance [online factsheet] (http://www.epha.org/a/4088, accessed 5 April 2011).

17. Dales R et al. Quality of indoor residential air and health. Canadian Medical Association Journal, 2008, 179:147-152.
18. Besaratinia A, Pfeifer GP. Second-hand smoke and human lung cancer. Lancet Oncology, 2008, 9:657-666.

19. Sflomos C, Papadopoulou R, Athanasiou K. Temperature and time effects on mutagen production in cooked lamb meat. Mutagenesis, 1989, 4:228-229.

20. Hill M, Giacosa A. The Mediterranean diet. European Journal of Cancer Prevention, 1992, 1:339-340.

21. Willett WC. Diet and health: what should we eat? Science, 1994, 264:532-537.

22. Cancer and diet. Athens, Greece, Proceedings of the annual meeting of the Hellenic Cancer Society, March 2004.

23. Trichopoulou A et al. Adherence to a Mediterranean diet and survival in a Greek population. New England Journal of Medicine, 2003, 348:2599-2608.

24. Slimani $\mathrm{N}$ et al. European Prospective Investigation into Cancer and Nutrition (EPIC) calibration study: rationale, design and population characteristics. Public Health Nutrition, 2002, 5(6B):1125-1145.

25. Reddy BS. Prevention of colon carcinogenesis by components of dietary fiber. Anticancer Research, 1999, 19(5A):3681-3683.

26. Vassilopoulos PP et al. Colorectal cancer trends by anatomic sides, age and staging. A twenty-year study of 1412 Greek cases. Anticancer Research, 2000, 20(6C):4773-4776.

27. Food-based dietary guidelines in Europe. EUFIC Review 10/2009. European Food Information Council (EUFIC) [online factsheet] (http://www.eufic.org/article/en/expid/food-based-dietaryguidelines-in-europe/, accessed 5 April 2011).

28. Levi F et al. Worldwide patterns of cancer mortality, 1990-1994. European Journal of Cancer Prevention, 1999, 8:381-400.

\section{Noncommunicable diseases}

Current evidence indicates that 4 types of noncommunicable diseases - cardiovascular diseases, cancers, chronic respiratory diseases and diabetes - make the largest contribution to mortality in the majority of low- and middleincome countries and require concerted, coordinated action. These diseases are largely preventable by means of effective interventions that tackle shared risk factors, namely: tobacco use, unhealthy diet, physical inactivity and harmful use of alcohol. In addition, improved disease management can reduce morbidity, disability, and death and contribute to better health outcomes.

Source: 2008-2013 Action plan for the Global Strategy for the Prevention and Control of Noncommunicable Diseases 